\title{
Recommendations for the development of national plans for rare diseases
}

\author{
Albert Van der Zeijden*, Jolanda Huizer \\ From 5th European Conference on Rare Diseases (ECRD 2010) \\ Krakow, Poland. 13-15 May 2010
}

Rare diseases are a threat to the health of EU citizens, in so far as they are life-threatening or chronically debilitating diseases with a low prevalence and a high level of complexity. Despite their rarity, there are so many different types of rare diseases that millions of people are affected. The focus on rare diseases and the recognition of the fact that rare diseases have common issues in a public health perspective and require specifically targeted policies, is a relatively new achievement in most EU member states. There is at present great variability among countries about the type of services provided to rare disease patients and the accessibility to these services. Following the Council Recommendations, each Member State should (preferably by the end of 2013) establish and implement plans or strategies for rare diseases at the appropriate level. The aim is to ensure that all patients with a rare disease in Europe have equal access to high-quality care, including diagnostics, treatments and rehabilitation. The European Project for Rare Diseases National Plans Development (EUROPLAN), has the task of elaborating documents to facilitate the establishment and implementation of National Plans or Strategies. EUROPLAN has defined a National Plan or Strategy as a set of integrated and comprehensive health and social policy actions for rare diseases, to be developed and implemented at national level, and characterised by identified objectives to be achieved within a specified timeframe. The EUROPLAN guidance document (recommendations) provides a set of "tools and examples" on how activities for rare diseases can be organised at national (and European) level on different areas, e.g. the coding (and traceability) of rare diseases,

*Correspondence: avanderz@xs4all.nl

Dutch Steering Committee OD, Laan van Nieuw Oost Indie 334, 2593 CE, The Hague, The Netherlands research, centres of expertise and the empowerment of patient organisations for rare diseases.

(http://www.europlanproject.eu)

Published: 19 October 2010

doi:10.1186/1750-1172-5-S1-03

Cite this article as: Van der Zeijden and Huizer: Recommendations for the development of national plans for rare diseases. Orphanet Journal of Rare Diseases 2010 5(Suppl 1):03.
Submit your next manuscript to BioMed Central and take full advantage of:

- Convenient online submission

- Thorough peer review

- No space constraints or color figure charges

- Immediate publication on acceptance

- Inclusion in PubMed, CAS, Scopus and Google Scholar

- Research which is freely available for redistribution

Submit your manuscript at www.biomedcentral.com/submit
C Biomed Central 